\title{
Assessment of soda ash calcination treatment of Turkish trona ore
}

\author{
Sibel Gezer ${ }^{1, a}$ and Umit Atalay ${ }^{2}$ \\ ${ }^{1}$ Republic of Turkey Ministry of Energy and Natural Resources, Nuclear Energy Project Implementation Department, \\ Ankara, Turkey \\ ${ }^{2}$ Middle East Technical University, Mining Engineering Department, Ankara, Turkey
}

\begin{abstract}
Trona is relatively rare, non-metallic mineral, $\mathrm{Na}_{2} \mathrm{CO}_{3} \cdot \mathrm{NaHCO}_{3} \cdot 2 \mathrm{H}_{2} \mathrm{O}$. The pure material contains $70.3 \%$ sodium carbonate and by calcination the excess $\mathrm{CO}_{2}$ and water can be driven off, yielding natural soda ash. The terms soda ash and sodium carbonate are used interchangeably. Trona calcining is a key process step in production of soda ash (sodium carbonate anhydrate) from the relatively cheap trona ore. The calcination reaction may proceeds in a sequence of steps. Depending on the conditions, it may result in formation of either sodium carbonate monohydrate $\left(\mathrm{Na}_{2} \mathrm{CO}_{3} \cdot \mathrm{H}_{2} \mathrm{O}\right)$, sodium sesquicarbonate or weigschederite $\left(\mathrm{Na}_{2} \mathrm{CO}_{3} \cdot 3 \mathrm{NaHCO}_{3}\right)$. The Beypazar1 Turkish trona deposit is the second largest deposit in the world with the content of $84 \%$ trona. The decomposition of trona appeared to be a single stage process across the temperature range studied $\left(150-200{ }^{\circ} \mathrm{C}\right)$ with the representative samples of different size fractions in the draught up metallurgical furnace. The optimum particle size and calcination time were $-6.35 \mathrm{~mm}$ and 30 minutes, respectively, at calcination temperature of $175{ }^{\circ} \mathrm{C}$ in a metallurgical furnace. Microwave-induced dry calcination of trona was possible and 5 minutes of calcination time at a power level of 900 was sufficient for complete calcination of $-6.35 \mathrm{~mm}$ feed. This includes short time calcinations with the goal of improving economics and simplifying the thermal process.
\end{abstract}

\section{Introduction}

Soda ash is the common name for sodium carbonate $\left(\mathrm{Na}_{2} \mathrm{CO}_{3}\right)$, a compound that has achieved significant economic importance because of its intrinsic role in the manufacturing of glass. The occurrence, preparation and uses of natural soda ash have been known since ancient ages. Soda ash has wide usage areas in chemical, detergent, soap and paper industries, in flue gas desulphurization (FGD) systems and in water treatment systems.

Production of the alkaline materials sodium carbonate and potassium carbonate (which were recognized rather late as chemically distinct) was carried out from ancient times until the 1800 s by combustion of marine and land vegetation, followed by calcination at red heat and leaching of ash. The term soda ash originates from this process [1].

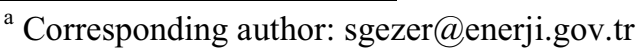


Presently, the well-known sodium carbonate minerals used in production of soda ash are trona $\left(\mathrm{Na}_{2} \mathrm{CO}_{3} \cdot \mathrm{NaHCO}_{3} \cdot 2 \mathrm{H}_{2} \mathrm{O}\right)$, thermonatrite $\left(\mathrm{Na}_{2} \mathrm{CO}_{3} \cdot \mathrm{H}_{2} \mathrm{O}\right)$ and natrone $\left(\mathrm{Na}_{2} \mathrm{CO}_{3} \cdot 10 \mathrm{H}_{2} \mathrm{O}\right)$. Only trona with $70.3 \% \mathrm{Na}_{2} \mathrm{CO}_{3}$ content is of commercial interest.

Trona deposits are normally mechanically mined. The method uses conventional, either continuous or longwall mining technique or combination of them. Then, the raw trona can be processed by different methods such as sesquicarbonate, monohydrate, alkali extraction and carbonation processes. There are dominantly two, sesquicarbonate and monohydrate processes, used to convert mined trona into either pure soda ash, or sodium carbonate $\left(\mathrm{Na}_{2} \mathrm{CO}_{3}\right)$. In the sesquicarbonate process, the trona ore is dissolved in an aqueous solution and after separation of the resulting solution from the insolubles, sodium sesquicarbonate is crystallized from the solution by cooling. The sesquicarbonate crystals are then separated from the mother liquor and finally, calcined to recover soda ash (anhydrous sodium carbonate). In the monohydrate process, the trona ore is first calcined to convert its bicarbonate content to sodium carbonate, and is then dissolved in water. Then the resulting solution is separated from the insoluble and sodium carbonate monohydrate is precipitated to evaporative crystallization. The monohydrate crystals are then separated from the mother liquor and dried to recover soda ash [2].

\subsection{Beypazarı Trona deposit in Turkey}

The Turkish natural soda (trona) deposit was discovered in Beypazarı by the Mineral Research and Exploration Institute (MTA) in 1979 during coal exploration. The Beypazarı district is a large area of volcano-sedimentary rocks in the interior of central Anatolia, Turkey approximately $100 \mathrm{~km}$ northwest of Ankara. The trona deposit is present 130-140 m deep, in layers which are thicker and richer in the quality compared to the ores in Wyoming (USA). The Beypazar1 Turkish trona deposit is the second largest deposit in the world (total reserves about 300 million tons) with $84 \%$ trona content.

The Beypazarı trona deposit consists of two lensoidal bodies named as the upper (seam) and lower vein (seam). Due to limited development and preparation work in the mine, the samples named as U3, U4, U5 and U6 were taken from different layers in the upper vein and were mixed to prepare the representative trona ore sample. Characteristics of these layers are given in Table 1.

Table 1. Characteristics of samples taken from different layers.

\begin{tabular}{|l|c|c|c|c|}
\hline & U3 & U4 & U5 & U6 \\
\hline $\mathrm{Na}_{2} \mathrm{CO}_{3}$ & 34.48 & 43.06 & 43.09 & 43.44 \\
\hline $\mathrm{NaHCO}_{3}$ & 27.84 & 37.76 & 35.45 & 35.25 \\
\hline Total alkalinity, \% $\mathrm{Na}_{2} \mathrm{CO}_{3}$ & 52.04 & 66.88 & 65.46 & 65.69 \\
\hline Trona, \% & 73.53 & 91.82 & 91.88 & 92.63 \\
\hline
\end{tabular}

The dominant mineral in the deposit is trona along with some nahcolite, trace amounts of pirssonite and thermonatrite. Calcite, zeolites (analcime, klinopitolite), feldspar and clays are the most common gangue minerals within the associated rocks of the trona deposit. The trona crystals, which are generally white and occasionally grayish due to the presence of impurities, formed in massive beds and disseminated crystals in claystone and shale.

\subsection{Trona calcination}

Trona is relatively rare, non-metallic mineral, $\mathrm{Na}_{2} \mathrm{CO}_{3} \cdot \mathrm{NaHCO}_{3} \cdot 2 \mathrm{H}_{2} \mathrm{O}$. The pure material contains $70.3 \%$ sodium carbonate and by calcination the excess $\mathrm{CO}_{2}$ and water can be driven off, yielding natural soda ash. The terms soda ash and sodium carbonate are used interchangeably. Soda ash is a white, anhydrous, powdered or granular material containing much above $99 \%$ sodium carbonate $\left(\mathrm{Na}_{2} \mathrm{CO}_{3}\right)$ when shipped. The accepted commercial standard for soda ash is expressed in terms of the total equivalent sodium oxide $\left(\mathrm{Na}_{2} \mathrm{O}\right)$ content [3] . 
Trona calcining is a key process step in production of soda ash (sodium carbonate anhydrate) from the relatively cheap trona ore. It is accomplished by heating trona to an appropriate temperature to remove $\mathrm{CO}_{2}$ and $\mathrm{H}_{2} \mathrm{O}$. The calcination reaction may proceed in a sequence of steps. Depending on the conditions, it may result in formation of sodium carbonate monohydrate $\left(\mathrm{Na}_{2} \mathrm{CO}_{3} \cdot \mathrm{H}_{2} \mathrm{O}\right)$, sodium sesquicarbonate or weigschederite $\left(\mathrm{Na}_{2} \mathrm{CO}_{3} \cdot 3 \mathrm{NaHCO}_{3}\right)$. The rate of formation and subsequent decomposition of these compounds are vital in the overall efficiency of the calcinations stage of process. The decomposition reaction occurs according to the following equation:

$$
2\left(\mathrm{Na}_{2} \mathrm{CO}_{3} \cdot \mathrm{NaHCO}_{3} \cdot 2 \mathrm{H}_{2} \mathrm{O}\right) \Rightarrow 3 \mathrm{Na}_{2} \mathrm{CO}_{3}+5 \mathrm{H}_{2} \mathrm{O}+2 \mathrm{CO}_{2} \text {. }
$$

The mechanism is based on thermal treatment of the ore that effects its decomposition and elimination of gangue minerals. To produce the probable main product, dense soda ash, from trona requires the stoichiometry given in Eq. 1.

The calcining step is a simple and exceedingly demanding operation. Trona can be either decomposed or calcined (Eq. 1) at any temperature over $70{ }^{\circ} \mathrm{C}$, but the rate does not become reasonable until temperature is above $120^{\circ} \mathrm{C}$. Above approximately $800{ }^{\circ} \mathrm{C}$ the entire ore fuses [4].

Currently, conversion of trona into soda is performed industrially by calcining the raw ore in rotary calciners at temperature of $120{ }^{\circ} \mathrm{C}$ or higher. It is postulated that the decomposition reaction according to Eq. 2 occurs only at temperatures beyond $160^{\circ} \mathrm{C}$. At lower temperatures wegscheiderite $\left(\mathrm{Na}_{2} \mathrm{CO}_{3} \cdot 3 \mathrm{NaHCO}_{3}\right)$ and sodium carbonate monohydrate $\left(\mathrm{Na}_{2} \mathrm{CO}_{3} \cdot \mathrm{H}_{2} \mathrm{O}\right)$ form as intermediates [5]. Under dry conditions, trona is reported to be stable till $\sim 55-57^{\circ} \mathrm{C}$. Above this temperature trona starts to decompose at a slow rate:

$$
\begin{gathered}
3\left(\mathrm{Na}_{2} \mathrm{CO}_{3} \cdot \mathrm{NaHCO}_{3} \cdot 2 \mathrm{H}_{2} \mathrm{O}\right)(\mathrm{s}) \Rightarrow\left(\mathrm{Na}_{2} \mathrm{CO}_{3} \cdot 3 \mathrm{NaHCO}_{3}\right)(\mathrm{s})+2 \mathrm{Na}_{2} \mathrm{CO}_{3}(\mathrm{~s})+6 \mathrm{H}_{2} \mathrm{O} \\
2\left(\mathrm{Na}_{2} \mathrm{CO}_{3} \cdot 3 \mathrm{NaHCO}_{3}\right)(\mathrm{s}) \Rightarrow 5 \mathrm{Na}_{2} \mathrm{CO}_{3}(\mathrm{~s})+3 \mathrm{H}_{2} \mathrm{O}+3 \mathrm{CO}_{2} .
\end{gathered}
$$

Microwave-induced calcination of trona has the potential to re-evaluate many aspects currently necessary in the conventional processing of trona into soda ash. This includes high temperature calcination, with the goal of improving economics and simplifying the process.

The amount of microwave energy that the trona absorbed is directly related with the operated power of microwave. The measurements of microwave are of input (directly from the generator), reflected (back to the generator from the load) and transmitted powers (through the load). The power absorbed by the trona is then calculated by subtracting the transmitted and reflected power from the input power. The studies in the literature showed that only trona in the solution was capable of absorbing most of the input power. Dry trona did not prove to be a very good absorbent alone. It is interesting to note that pure water only absorbed approximately a tenth of the power that trona in solution absorbed, and when compered the reactor load was near zero. This is conclusive result that trona in a solution is a very good microwave absorbent and an excellent candidate for decomposition in the microwave field [6].

\section{Experimental}

\subsection{Samples}

The trona samples used in this study were taken from the trona deposit in Beypazar1, Turkey. The used samples were taken from different layers in the upper vein and were mixed to prepare the representative trona ore samples. The studies showed that trona is present in 130-140 $\mathrm{m}$ dep, in layers, which are thicker and richer in quality compared the ones in Wyoming (USA).

Mineralogical analyses show that the trona ore consists of the two different mineralogical structures that is massive and crystalline. The principal sodium carbonate minerals are trona and 
minor nahcolite, trace amounts of pirssonite and thermonatrite in the Beypazar1 ore. Trona and dolomite are associated throughout the trona zone. Calcite, zeolites, feldspar and clays are the most common gangue minerals within the rocks of deposit. The chemical analysis of representative samples is shown in Table 2. The results of the thermogravimetric analysis (TGA) test of representative sample is given in Figure 1.

Table 2. Chemical analysis of representative Beypazarı trona sample.

\begin{tabular}{|l|c|}
\hline Component & Weight, \% \\
\hline $\mathrm{NaHCO}_{3}$ & 33.00 \\
\hline $\mathrm{Na}_{2} \mathrm{CO}_{3}$ & 38.59 \\
\hline Total Alkalinity, \% $\mathrm{Na}_{2} \mathrm{CO}_{3}$ & 59.40 \\
\hline Insolubles & 15.30 \\
\hline $\mathrm{NaCl}$ & 0.025 \\
\hline $\mathrm{Na}_{2} \mathrm{SO}_{4}$ & 0.026 \\
\hline Loss of ignition & 25.27 \\
\hline TRONA & 84.70 \\
\hline
\end{tabular}

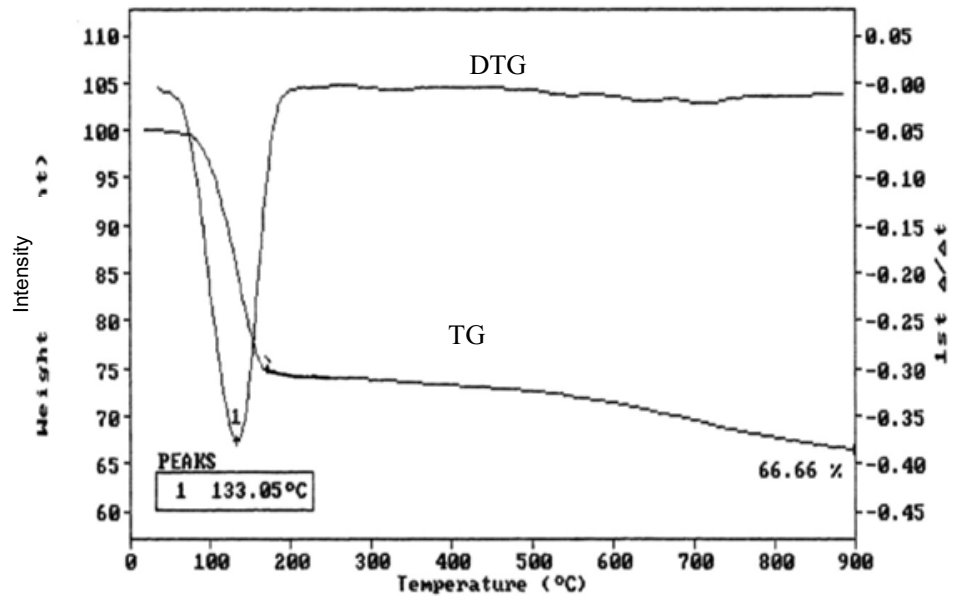

Figure 1. TG and DTG curves of representative Beypazarı trona ore samples.

\section{Results and discussion}

Calcination process was investigated by using the draught up furnace. The sample solids were contained in a glass vessel and air introduced into the system via a distributor. Experiments were conducted at three different temperatures, 150,175 and $200{ }^{\circ} \mathrm{C}$. The adjustment of the airflow created some problems. At a low air velocity the solids were in either a packed-bed or fixed-bed state, while solids were thrown away from the heating zone at a high airflow rate. During the tests, attention was given to the adjustment of compressed air flow. At a low airflow rate, the solid samples were in either a packed-bed or fixed bed state and adverse effect of insufficient air flowing was observed noticeably for the small particle size of $-3.35 \mathrm{~mm}$. As the gas velocity increased, the lifting force eventually overcame the weight of the particles and eliminated the interparticle forces, and the air with exhausted gases of $\mathrm{CO}_{2}$ and $\mathrm{H}_{2} \mathrm{O}$ found a way to go through the interparticle void space. When the gas flow was too high the tap was thrown away from the top and then the possibility of solid leaking increased. However, under the conditions of good adjustment of air flowing and temperature, trona decomposition was carried out for up draught in shorter time than it was in the muffle furnace. 


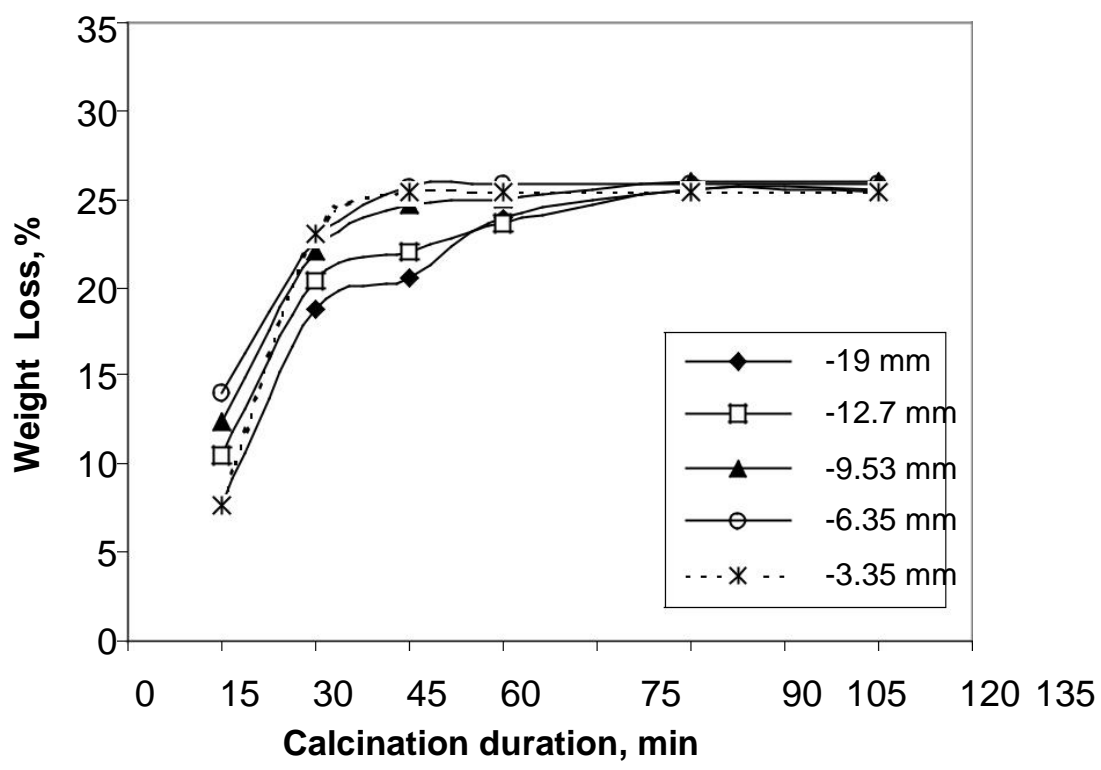

Figure 2. Draught up calcination of different particle size at $150{ }^{\circ} \mathrm{C}$.

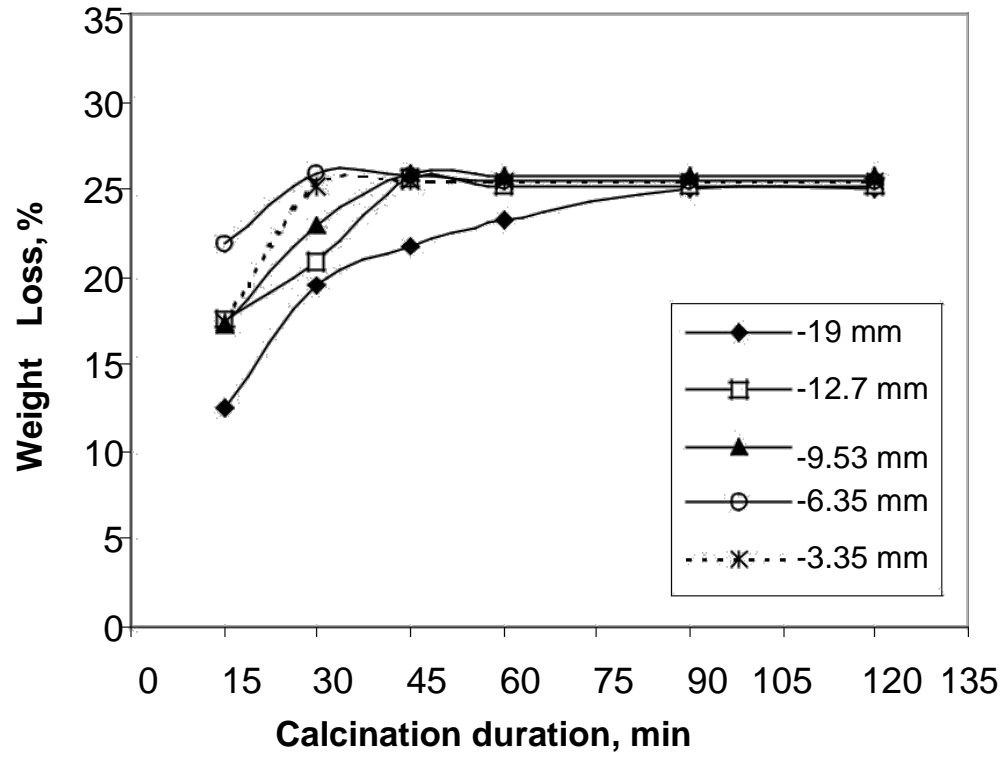

Figure 3. Draught calcination of different particle size at $175^{\circ} \mathrm{C}$.

Decomposition of trona appeared to be a single stage process across the temperature range studied (150-200 $\left.{ }^{\circ} \mathrm{C}\right)$ and the complete weight loss occurred in a short time. It is possible to interpret that such short time decomposition might relate directly to the heating system and air flowing through the particles. Calcination was not continued to the longer that of 100-120 minutes. It was observed that complete calcination was realized in 80-90 minutes for coarse particle size in draught calcination. 


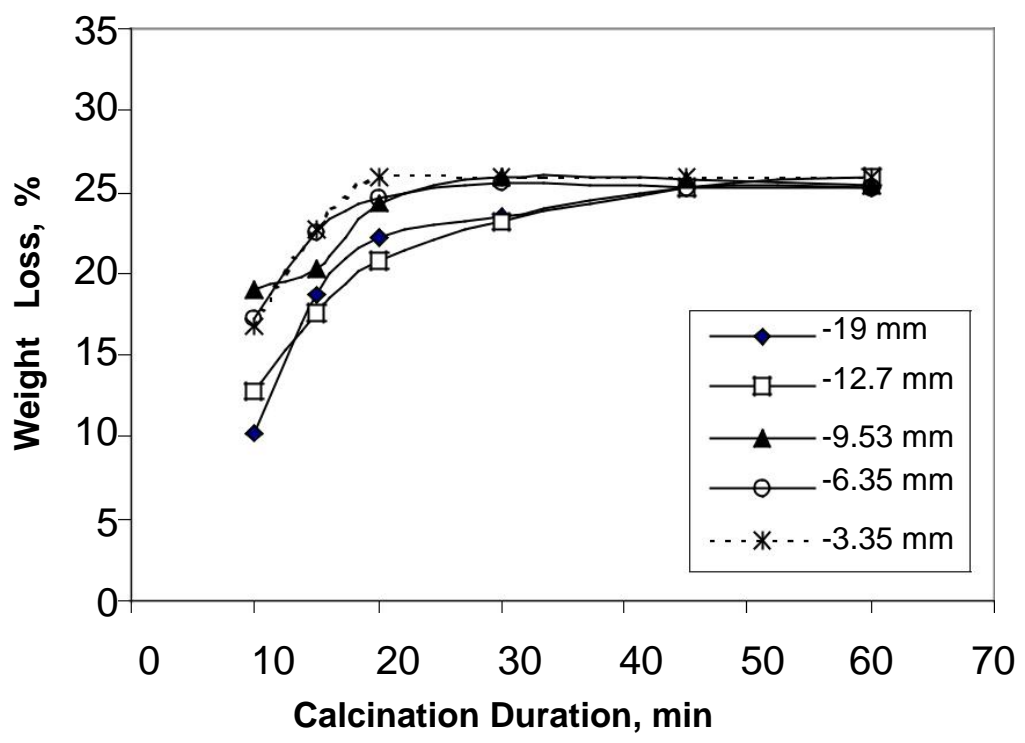

Figure 4. Draught calcination of different particle size at $200{ }^{\circ} \mathrm{C}$.

Microwave-induced calcination of trona has the potential to re-evaluate many of the aspects currently necessary in the conventional processing of trona into soda ash. It includes short time calcination, with the goal of improving economics and simplifying the process.

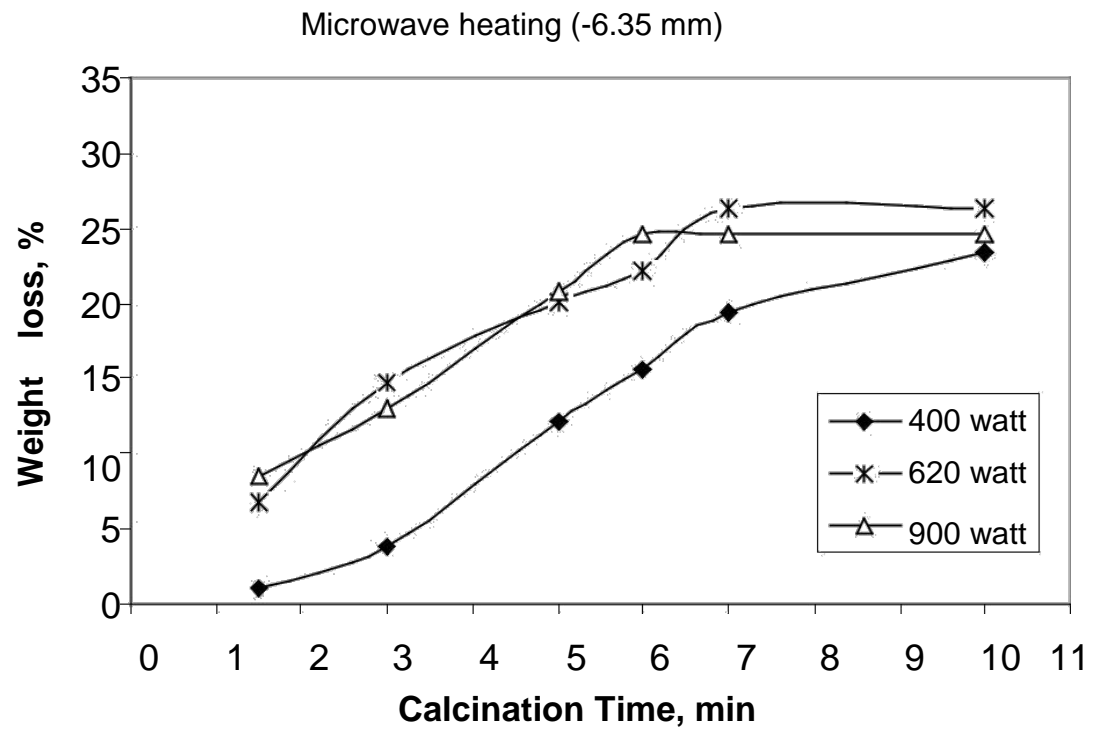

Figure 5. Effect of calcination time on the weight loss of $-6.35 \mathrm{~mm}$ trona.

The goal of this part of the study were to explore the feasibility of producing soda ash from trona using a microwave process and to investigate the best possible process for converting all of sodium bicarbonate $\left(\mathrm{NaHCO}_{3}\right)$ content in trona to the required value into either sodium carbonate or soda ash 
as well as to study the kinetics of reaction. One series of experiment was conducted in microwave using dry samples so the process was named as the dry type microwave calcination [7].

The experiments were intended to compare effects of microwave heating, versus conventional heating. Calcination was completed in 30 minutes in conventional heating, whereas the same weight loss value was obtained in very short calcination time as 6-7 minutes depending on the applied power for the particle size of $-6.35 \mathrm{~mm}$. Dry microwave calcination of $-6.35 \mathrm{~mm}$ particles showed that the weight loss increased with increasing calcination duration and power setting.

The results plotted in Figure 5 showed that both -3.35 and $-6.35 \mathrm{~mm}$ samples would be completely calcined in 10 minutes, besides $-6.35 \mathrm{~mm}$ sample would have already completed calcination process in 7 minutes. It shows that the calcination time was not sufficient for complete calcination of $-9.53 \mathrm{~mm}$ particle samples.

\section{Conclusion}

Based on the experimental results, the following conclusions can be drawn.

1. Trona can be decomposed at any temperature over $70{ }^{\circ} \mathrm{C}$, but the process rate does not become reasonable below $120^{\circ} \mathrm{C}$.

2. Thermal decomposition of trona at low calcinations temperatures produces sodium carbonate monohydrate $\left(\mathrm{Na}_{2} \mathrm{CO}_{3} \cdot \mathrm{H} 2 \mathrm{O}\right)$ and wegschederite $\left(\mathrm{Na}_{2} \mathrm{CO}_{3} \cdot 3 \mathrm{NaHCO}_{3}\right)$ as intermediate products.

3. Calcination of $-6.35 \mathrm{~mm}$ feed at $175{ }^{\circ} \mathrm{C}$ is the muffle furnace can be sufficiently completed after $30 \mathrm{~min}$.

4. The weight loss $25.44 \%$ after complete calcination is explained by removal of crystal water and exposure of $\mathrm{CO}_{2}$.

5. Microwave-induced dry calcination of trona was possible and 5 minutes of calcination time at a power level of $900 \mathrm{~W}$ was sufficient for complete calcination of $-6.35 \mathrm{~mm}$ feed.

\section{References}

1. C. Thieme, Ullmann's Encyclopedia of Industrial Chemistry, A24, 299 (2000)

2. T. Eggeman, Kirk-Othmer Encyclopedia of Chemical Technology, (2011)

3. USGS, Soda Ash, Mineral Industry Surveys, (Ann. Rev., U.S. Geolo. Surv.,1, 2002)

4. M. Doğan, C .Güldür, G. Doğu, T. Doğu, in Sprey Dryer., J.Chem. Tech. Biotechnol., 68, 157 (1997)

5. M.C. Ball, A.N. Strachan, R.M. Strachan, J.Chem. Soc. Faraday Trans. 87(12), 1911 (1991)

6. R.D. Streuber, C.Y.Cha, in Proceedings of the First International Soda Ash Conference-Rock Springs (Wyoming, 2, 185, 1998)

7. S. Orgul, Ph.D. Thesis, METU, Ankara, Turkey, (2003) 